\title{
International Migration and Federative Co-ordination in Brazil: São Paulo and Porto Alegre Case Studies between 2013 and 2016
}

\author{
Guilherme Arosa Prol Otero* \\ Gabriela Spanghero Lotta**
}

\begin{abstract}
This article analyses the co-ordination between national and municipal governments in Brazil regarding migration policy between the years of 2013 and 2016, using the concept of policy institutional arrangements and case studies of two Brazilian cities, São Paulo and Porto Alegre. The results reveal that the City of São Paulo government has advanced considerably in the sense of institutionalisation of the subject in the municipality by decentralising skills and assuming responsibilities for its migrant population, with relative autonomy from federal government. The City of Porto Alegre government shows a less institutionalised arrangement, with little technical and financial capability, less autonomy from federal and state governments, and great emphasis on civil society participation. Finally, it is advocated that the regulation of the New Migration Law may deal with a series of problems in the current federative arrangement, constituting federative-articulated policies, with greater capacity for public policy implementation, and more active participation of subnational governments in the development of the national migration policy.
\end{abstract}

Keywords: international migration; migration policy; institutional arrangement; public policies; integration policies.

\section{Introduction}

Since the turn of the century, international migration has become increasingly prominent in public debate and in the governmental agenda of many countries. Nowadays, it is one of the central themes in electoral disputes in North America and Europe. In Brazil, in spite of being a major recipient of immigrants from the mid-nineteenth century on, the

\footnotetext{
* Federal University of ABC (UFABC), Santo André-SP, Brazil; gapotero@gmail.com. ORCID iD 0000-00028255-1855.

** Getúlio Vargas Foundation (FGV), São Paulo-SP, Brazil; gabriela.lotta@gmail.com. ORCID iD 0000-00032801-1628.
} 
migration theme remained far from recent political leaders' priorities. This was partly due to the small number of immigrants in the country, less than $1 \%$ of the total population, and partly to the more significant phenomenon of Brazilian emigration, around $2 \%$ of the total population (MRE 2015; UN 2016), even though emigration has little impact in this country of continental dimensions. However, in this century, the pattern of human mobility in Brazil (and in Latin America) has undergone major changes and brought new challenges to the federal government, and especially to municipal governments, which are even more impacted.

At present, the Venezuelan exodus is the main migratory phenomenon in South America. But a few years ago, the arrival of migrants from Haiti on the continent placed migration at the centre of public debate. More than 67000 Haitians entered Brazil between 2010 and 2016 (IOM and IPPDH 2017: 42). This fact exposed a number of shortcomings and gaps in Brazil's migration policy, in particular in the vertical co-ordination between federal government (decision-making and formulation) and the municipalities where immigrants arrived (hosting and integration).

Although Brazil has institutionally and normatively evolved in the migration area, by sanctioning a New Migration Law in 2017 and promoting local policies aimed at migrant populations, federative co-ordination is still the weak link. Article 120 of the New Migration Law aims to 'coordinate and articulate sectoral action implemented by the Federal Executive government, in cooperation with the States, the Federal District and the Municipalities, with the participation of civil and international organisations, and private entities' (Article 120, Federal Law 13445/2017). Nevertheless, the article is pending regulation. Thus, it is essential to address this gap concerning human mobility in Brazilian Public Policy.

This paper intends to analyse the federative co-ordination of Brazilian migration policy, using an analytical approach of institutional arrangements of public policies, and two case studies in which the vertical relationship between municipal and federal levels is prominent, but whose outcomes diverged: the cities of Porto Alegre and São Paulo.

There are two main reasons why the study of these cases and the deeper understanding of how Brazil dealt with its migration challenges back then is important. The first one is the Venezuelan exodus, which has reached 4.6 million people, $80 \%$ of which are in Latin America (UNHCR and IOM 2019), amounting to the largest migration crisis in the region and one of the biggest in the world. The strategies and policies that host countries and cities are implementing to manage these flows and integrate Venezuelan refugees and migrants will be decisive to regional integration, politics and economy. The second reason is the prominence cities have achieved in migration and refugee studies, as well as many other contemporary agendas such as development, economic inequality or environmental sustainability (Sassen 2005; UN 2017). As illustrated in the chapters that follow, Brazilian municipalities have a great deal of political autonomy and several responsibilities, along with many constraints to exert its powers, which become more apparent when they need to address large migration flows. Similar challenges are found in cities throughout the world and should continue to do so as the world population becomes increasingly urban, and increasingly on the move. Ultimately, the role of cities on migration policy connects to 
the larger theoretical debate on the changing relationship between nation-states, citizenship and migrant's rights (Zolberg 2000; Sassen 2005; Baraldi 2014; Amrith 2015).

After the methodological exposition, the article introduces theoretical concepts relevant to the debate, such as migration policy, integration policies, and decentralisation in the Brazilian federal state, which are helpful to understand the role of subnational governments in the governance of human mobility. Thereafter, we move into the analysis of the institutional arrangement at the federal level and describe how federative co-ordination is structured (or not). Then, case studies of two municipalities are presented. Lastly, final considerations bring conclusions about data and case study reports, include difficulties in effective decentralisation of the policy and gaps in federative relationship, and present some possible way to overcome them.

\section{Methodology}

The research was oriented by an analytical approach to institutional arrangements of public policies, defined as:

[S]et of rules, mechanisms and processes that define the particular way in which actors and interests are coordinated in the implementation of a specific public policy. Arrangements endow the state with the capacity to execute its objectives [...]; and determine who participates in the process, its objectives, and how interaction between actors takes place (Gomide and Pires 2014: 19-20, translated by the authors).

Such an approach enables a comprehensive analysis of public policies that embrace a great diversity of actors, which are complex and intersectorial in nature, and which involve federative co-ordination in at least one of the phases of the policy cycle. Lotta and Favareto (2015) propose four axes of analysis: i) the horizontal axis/intersectoriality: this concerns the sectoral articulation, within the same sphere of power; ii) the vertical axis/ federative relations: this refers to the relations between federal, state, and municipal levels; iii) the participation axis: this refers to the permeability for participation of non-state actors; iv) the territoriality axis: this assumes that local factors are conditioning to the success of investments made and investigates whether the institutional arrangement takes such factors into account. Each axis is analysed according to the three phases of the policy cycle: formulation, implementation, and monitoring and evaluation. This paper focuses on the vertical axis, addressing the other three when appropriate, so as to make clear the relationship among actors.

In this research, the analysis of institutional arrangements of two municipalities intends to describe how migration policy was structured, which actors were involved, and the co-ordination mechanisms among them. In what follows, it will be argued that municipal policies on migration issues are quite recent in Brazil, and they just took shape during the period analysed. Nonetheless, the study focuses on the federative relationship between 
the two municipalities and federal government. The analysis of the federative co-ordination is identified as a major gap in the literature review or, to use the term of Alvesson and Kärreman (2007), the 'breakdown' of migratory studies in Brazil. That is why the objects of analysis are the competences of each level of government, actors involved in formulation and implementation, actors' co-ordination, and policy-financing models.

Case study methodology was used, as this allows a detailed analysis of the object within its context (Borges 2007). The municipalities of Porto Alegre and São Paulo were selected for three reasons: i) both have some historical background experience in municipal policies directed at migrants and/or refugees; ii) both were significantly impacted by the Haitian migratory flow; and iii) the two capital cities co-ordinated actions with federal government that resulted in the implementation of specific public policies (notably, the Reference and Assistance Centres for Immigrants - CRAI in the Portuguese acronym). Also, this choice follows methodological criteria. Cases to be studied should not be selected at random, but rather chosen according to the evidence that matches the objectives of the research (Eisenhardt 1989), with similar values in dependent variables (Borges 2007). As for the timeframe selection, from 2013 to 2016, this relates to the period of greatest impact of the Haitian flow into the two state capitals. Also, the period analysed runs along one complete political cycle in municipal administration, within which the public policies were implemented.

Data and empirical research presented in this paper were collected for the study from Otero (2017). Empirical research consisted of interviews with four policymakers, whose responsibilities were directly related to the migratory policies under analysis.

Table 1 - Research Interviews

\begin{tabular}{ll}
\hline Respondents & Institution where they worked between $\mathbf{2 0 1 3}$ and $\mathbf{2 0 1 6}$ \\
\hline 1 & $\begin{array}{l}\text { Co-ordination Office for Migrant Policy, } \\
\text { São Paulo Municipal Secretariat of Human Rights and Citizenship }\end{array}$ \\
\hline 2 & $\begin{array}{l}\text { Joined Secretariat of the Indigenous People and Specific Rights, } \\
\text { Porto Alegre Municipal Secretariat of Human Rights }\end{array}$ \\
\hline 4 & National Secretariat of Justice, Ministry of Justice \\
\hline 4 & National Immigration Council, Ministry of Labour \\
\hline
\end{tabular}

Interviews were conducted between January and March 2017, aiming at understanding the circulation of 'repertoires' within the current migration context, as well as the political approach of prominent authorities, and the relationship established among actors (Aragaki et al 2014). Questionnaires were semi-structured, providing interviews with more flexibility and making room for interaction and explanatory questioning when necessary (Aragaki et al 2014). We opted to keep respondents' anonymity.

The data collected in the interviews were compared to the data obtained from the literature review on migration and public policy in Brazil. Public documents were also investigated: institutional reports, meeting minutes, technical opinions, terms of reference, and relevant municipal legislation. Some data, such as federal transfer, were obtained via 
Information Access Law from competent agencies. Finally, one of the authors of this article worked at the Coordination Office for Migrant Policy in the City of São Paulo during the analysis timeframe, with direct access to information and to the dynamics among local actors.

\section{Theoretical references}

To provide further analysis of migration policy institutional arrangement, key concepts need to be recalled, such as decentralisation, institutional arrangement, and state capacity (from Public Policy Studies), migration policy, and local integration policies (from Migration Studies).

According to Arretche (2011), decentralisation may be defined as the local institutionalisation of technical conditions and capacities (financial, administrative, and human resources) for the implementation of public policy management, in order to ensure relative continuity in the supply of a given good or service. Different factors are likely to influence the decentralisation of a given policy: i) structural factors: political-administrative capacity and government-spending capacity; ii) institutional factors: legacy of prior policies (which may increase or decrease the costs of installing new policies), constitutional rules (which encourage or hinder decentralisation), and operational engineering of policies; iii) factors originated by political action: political culture, and federal government induction over subnational governments (Arretche 2011).

The 1988 Federal Constitution and the subsequent development of social policies over the last three decades in Brazil together formed a kind of federalism in which 'the federal government has regulatory authority to decisively influence the political agenda of subnational governments' (Arretche 2011: 17). For Arretche, the federal government plays the role of 'policy decision-making', while subnational governments play the role of 'policymaking.' This distribution of roles is configured in this manner because of three determining characteristics: spending power concentrated at the federal level, constitutional norms, and ministerial authority over certain policies. These characteristics are determinant for the involvement of municipal governments in migration issues, as detailed below.

This does not exclude some level of autonomy of local governments, including whether or not to adhere to policies and to adapt them to local contexts.

When constituent units are not required by the Constitution to enforce a given policy, it is up to each mayor or governor to decide on their membership. As a result, the federal government needs to formulate policy designs that make this decision appealing to mayors and governors. [...] By contrast, policies whose design mobilises distrust on the part of constituent units tend to reduce the chances of effectiveness (Arretche 2012: 23, translated by the authors).

This should help understand the challenges of effectively involving state and municipal authorities in Brazilian migration policy. Migration policy is the main instrument with 
which national governments aim to intervene in the flow of people to and from territories. For Czaika and De Haas (2011), it consists of laws, rules and policies implemented by national states with the objective of influencing the volume, origin and composition of migratory flows. Migration policy is anchored in the principle of sovereignty of modern states over their population and territory, which has guided the international system since the seventeenth century. One of the foundations of sovereignty is precisely that the state has the legitimate monopoly on mobility within its borders and that migrants are subject to these rules (Reis 2004; Gomes 2005).

Despite the existing policies related to human mobility at the federal level, there is growing protagonism of subnational governments in this field. Sassen (2005) states that immigration is a constitutive process of globalisation, and the cities have become strategic in the mobility of the workforce and formation of transnational communities. They have become, as she puts it, 'a site for new claims,' opening the possibility of new forms of citizenship (Sassen 2005: 39). After all, the impacts of migratory flows are most visibly experienced at the city level, because it is in this context that migrant people seek work, housing, health, education, security, and access to culture (in general, competences of the local level of government). It is in the city that the national and the 'foreigner' live daily: the cities are loci of tensions. According to Amrith (2015: 653), '[i]t is in the city where rights are given tangible expression in the lives of migrants.' This means that local policies have great potential for promoting citizenship, and guaranteeing rights to immigrants, even though there are barriers to access 'formal citizenship' at the national level (Tavares 2015). In addition to this, it is argued that local governments respond faster and more comprehensively to challenges posed by migratory flows (Fauser 2008) and find it easier to formulate policies specific to local reality and to mobilise local actors, such as companies and NGOs (Juzwiak, McGregor and Siegel 2014).

The scope of action of local governments is restricted to integration policies. Integration can be defined as 'the multidimensional process by which migrants become accepted into society, both as individuals and as groups. It generally refers to a two-way process of adaptation by migrants and host societies' (IOM 2011: 51). Successful integration must ensure legal status to immigrants, empower them to exercise their rights, and actively participate in their integration, without harm to their identities (Medina et al 2009; Juzwiak, McGregor and Siegel 2014).

Some researchers have proposed typologies for classifying local integration policies. One of the best known, by Alexander (2003), is based on the government's view on human mobility, and the relationship between the 'stranger' and the 'host.' It establishes four types of integration policies: (i) 'non-policy', when the administration views immigration as a transitory phenomenon; ii) guest-worker policy, when migration is characterised as transitory, and the local government outsources its responsibility to NGOs or to the federal government; iii) assimilationist, characterised by the attempt to discourage ethnic, cultural, and religious diversity; and iv) pluralist, which recognises the perpetuity of migration, its diversity and positive potential, tending to adopt pluralistic integration policies (Alexander 2003: 418). 
Although this typology is built upon the European context and the European way of dealing with the 'foreigner', it helps understand the different results obtained by the two municipal administrations that this paper took for analysis, considering local administrations' expectation about the migratory flows that reached them. When migration is considered as temporary and short-term, local management is unlikely to go beyond ad hoc participation and emergency provisions, as Alexander (2003) puts it, hoping that another level of government, or some other social actor, will deal with the problem (i.e. provide temporary shelter and access to essential public services). This type of integration policy prevails in Brazilian municipalities. It was found in Porto Alegre, despite their efforts in a different direction. In contrast, in cities where migration is a constitutive issue, such as São Paulo, there was greater incentive for the executive authority of the mayor to pursue permanent policies. This is acknowledged in interviews with respondents from the federal government.

Nevertheless, the will of a political leader is not the sole determinant of policymaking and enforcement. Literature shows that lack of co-ordination between national governments, local authorities, and civil society and lack of intersectorial co-ordination are obstacles to local policies for immigrants. Local administrations also have poor legal, political, technical, and financial capacities on migration issues, because national government traditionally concentrates such capacity on human mobility. Likewise, there is a persistent negative image of immigrants in the cities, characterised by racism and xenophobia, which adds to immigrants' invisibility, which does not call for public policy development (Medina et al 2009; Juzwiak, McGregor and Siegel 2014; IOM 2015). The cases researched in this paper face similar challenges, to be described in the following sections.

\section{Federal institutional arrangement}

Before analysing the two municipalities, it is necessary to outline the Brazilian context on migration policy and point out the main characteristics of the federal institutional arrangement. Since this is not the focus of the article, we will pay greater attention to federal co-ordination with subnational governments. Brazilian immigration policy was significantly influenced by the 'Foreigner's Statute,' as is the popular name of Federal Law 6 815 of 1980, a rule dating from a dictatorial period concerned with centralising migration control and the protection of the Brazilian labour market. This law was in force until 2017, surviving the end of the dictatorial period and the Federal Constitution of 1988. Although several of the assumptions embodied in Law 6815 were overruled by the Constitution, the migratory policy was maintained as an exclusively federal responsibility. The 1988 Federal Constitution, Art. 22, Items XIII, and XV, determines that it is the union's exclusive responsibility to legislate on matters of nationality, citizenship, naturalisation, immigration, emigration, entry, extradition, and expulsion of foreigners. In turn, Federal Law 9649 of 1998, which informs on ministerial competences, distributes the functions on migration as follows: 'XI - Ministry of Justice, h) nationality, immigration, and foreigners; XVII - 
Ministry of Foreign Relations, a) international politics; XIX - Ministry of Labour and Employment, g) immigration policy' (Federal Law 9649 of 1998, Art. 14).

There is no mention in legislation as to the role of subnational governments on migration issues, which is a discouraging factor for municipal governments to assume responsibility for local human mobility. Several authors call attention to this gap in migration policy, evoking local governments' role in integration and reception of migrants (Bógus and Rodrigues 2011; Coentro 2011; Câmara 2014). That is, when states and municipalities assume the reception of their immigrant population, they do so by omission of the federal government. As social policies are mostly subnational competences in the Brazilian federation, the same services and resources available to the rest of the population are used to supply immigrants' needs, without specific guidance, tools or services. Historically, however, state and local governments have also neglected the migration agenda, and civil society organisations have played the role of assisting immigrants (Amrith 2015).

In addition, there is no formal mechanism for inter-ministerial and federative co-ordination, and there is overlapping competence with regard to migration policy formulation, in particular between the Ministry of Justice and the Ministry of Labour. In spite of playing different roles, both made important decisions regarding migration through their collegiate bodies, the National Council for Refugees (CONARE), and the National Immigration Council (CNIg), respectively. An important indicator of the position of municipal governments in national migration policy is their lack of representation in both councils, whereas they have representatives in international organisations, NGOs affiliated to the Catholic Church, employers' unions, and workers' unions.

Several researchers emphasise this fragmentation and the problems arising from it. Andena (2013: 134-135) highlights the 'lack of rapport' of migration-related institutions, and the lack of a 'clear and well-defined' policy. Coentro (2011), Câmara (2014) and Dizner (2015) shed light on the competing views of these institutions. The Ministry of Foreign Relations (MRE) was pragmatic and foreign-policy oriented. The Ministry of Labour, through CNIg, showed openness to migration, combined with a focused perspective on labour migration, and a concern with the defence of the Brazilian worker. The Ministry of Justice had a dubious position: on the one hand, it addressed the issue of refuge and defence of citizens' rights; on the other hand, it is in charge of national and public security through the Federal Police, the agency responsible for migratory control in the country. Coentro (2011) goes further, pointing out the dispute for protagonism between the Ministry of Justice and the Ministry of Labour within the federal government, the shy involvement of the Ministry of Foreign Relations in the subject, and the lack of a more strategic and integrated position of authorities as additional problems arising from this fragmentation.

It may be that horizontal co-ordination within the federal government had problems, but effective relationship between states and municipalities were rare before 2013. When they occurred, policy decisions were made in Brasília, and municipalities played a passive role as places where the federal government's action took place, which reflects the separation proposed by Arretche. Civil society organisations (e.g. Archdiocesan Caritas of São 
Paulo, Migration and Human Rights Institute) played a more prominent role than local governments, for example by getting in agreement with the Ministry of Justice for the reintegration of refugees. This scenario began to change in 2014, when Haitian immigration hit the South and Southeast regions. In that year, there was a significant increase in the volume of voluntary transfers from the Ministry of Justice to municipal governments for projects related to immigrants and refugees, revealing a significant change in the vertical axis of the federal institutional arrangement.

Figure 1 - Voluntary transfer through partnership by the Ministry of Justice (currency in Brazilian Reais - BRL)

$B R L$

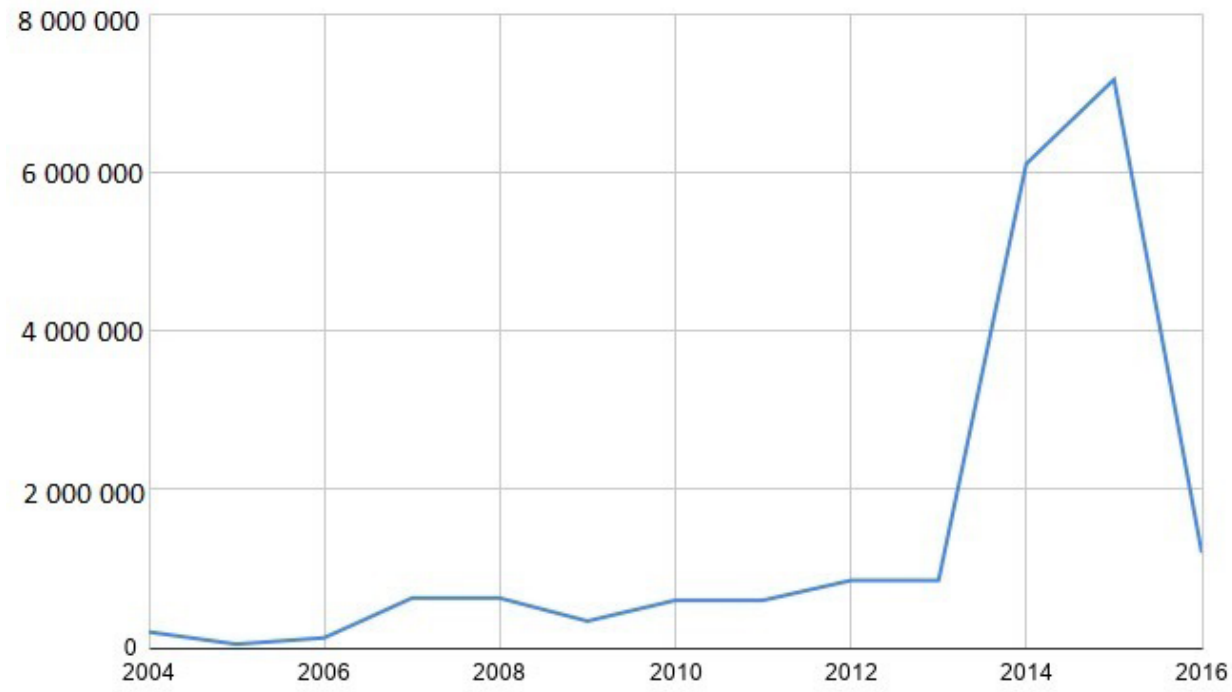

Source: Created by the authors

Moulin and Thomaz (2016) argue that the Haitian struggle had brought back criticism of the Foreigner's Statute. They highlighted 'the lack of a co-ordinated public policy that would establish clear responsibilities for governmental agencies, for the reception and integration of migrants' (Moulin and Thomaz 2016: 606). In fact, according to Respondent 4 , although policies are defined by federal government, 'operationalisation goes through cities and states [...] it was shocking to know that cities were not prepared to receive a large volume of people.' On the other hand, Respondent 3 recognises that the Haitian flow was very significant, because of its intensity, and because of the entrance path through the northern Brazilian State of Acre, one of the furthest, poorest and smallest in the country. However, he heightens the 'willingness of some leaders, whose attitudes exceeded the simple procedural response,' and recalls that the City of São Paulo had started the implementation of policies before 2014, a 'political decision' that was justified by former migration flows. 
Both federal government managers agree that it is at the municipal level that the effects of migration are felt. Respondent 3 states that 'the involvement of the cities is essential.' For him, 'federal government must formulate the national policy and the international affairs policy.' He also mentions that the theme of migration must integrate social policies and sees the need for 'complementarity between the federation's entities.' Also, Respondent 3 reports there has been an intention to constitute a National Governance Forum for Migration with the participation of subnational governments. The Forum is pending regulation (Respondent 3, interview, 24 January 2017).

Respondent 4 argues that the role of federal government is to co-operate with cities in which there is a greater presence of immigrants and refugees.

It is important that the federal government runs this process with common guidelines on migrant and refugee integration, and for cities and states to make their own [policies] based on national policy, taking into account local needs. That must be in the federative pact, if you are serving a larger and extra, unforeseen population, you need to know how you will have budget to meet this population, federal and state funding support to cities' (Respondent 4, interview, 30 March 2017; translated by the authors).

Respondent 3 argues that a 'lasting solution to the financial sustainability of local policies would be to guarantee continuous financing, a similar model to that adopted in Social Assistance Policy.' The Ministry tried to get the Immigrant and Refugee Reference Centre (CRAI) incorporated into the municipal budget but admits that 'this must have been one of the reasons why states and municipalities did not prioritise the policy' (Respondent 3, interview, 24 January 2017). The next section deals with municipal policy cases.

\section{Porto Alegre: social participation and distribution of competences}

The capital city of the State of Rio Grande do Sul, Porto Alegre has long been affected by migrations since its foundation in 1772 by Portuguese immigrants. Throughout the XIX century, it received large numbers of German, Italian, Polish and Spanish immigrants. Currently, due to its geographical position as neighbour to Argentina and Uruguay, Porto Alegre is one of the gateways to Mercosur, maintaining strong political and economic relations with these countries (Zamberlan et al 2013) and, consequently, receiving migrants from this region. According to civil society organisations, based on data from Federal Police records, and undocumented migrant estimates, there were about 32000 migrants in the municipality in 2013, or about $2 \%$ of the population (Zamberlan 2013).

The first Brazilian post-democratisation municipal law on migration was passed in Porto Alegre and concerned the theme of asylum. Municipal Law 8593 of 2000 was intended to authorise the municipal executive power to make 'agreements necessary to receive people enduring political persecution and refugees', as well as 'coordinate actions to ensure the assistance and integration of received persons.' In its regulatory decree, the 
policy was under the responsibility of the Co-ordination Office of Human Rights and Citizenship, and the Mayor's Office (Municipal Decree 13717 of 2002). After successive administrative and political changes at municipal level, the immigration policy was moved to the Adjunct Secretariat of Indigenous Peoples and Specific Rights (SAPIDE), within the Municipal Secretariat of Human Rights (SMDH). SAPIDE was created by Municipal Law 11399 of 2002, and allegedly responsible for 'coordinating and monitoring public policies directed at indigenous peoples [...] and promoting human rights for prisoners as well as refugees and immigrants,' according to their official website (SMDH s.d.).

Despite an apparent protagonism of the Porto Alegre City Hall, it is important to note that the law creating SAPIDE does not explicitly mention immigrants or refugees, indicating that the institutionalisation of the issue by City Hall was not complete (which, as shall be demonstrated, is a striking difference in relation to São Paulo). As Respondent 2 affirms, 'there was a lot of fear from the government to take up work with immigrants, [as] it was seen as another burden on the municipal government at the beginning of a financial crisis' (Respondent 2, interview, 16 March 2017).

This feeling of fear was not new. The 2000 Municipal Law was somehow a consequence of refugee resettlement since the 1950s, mainly hosted by religious entities, such as the Italian-Brazilian Centre for Migration Assistance and Instruction (CIBAI), as an alternative action to compensate for the omission of the state (Zamberlan, Corso, Filippin and Bocchi 2009). According to Respondent 2 (interview, 16 March 2017), to date, CIBAI is a reference entity in Porto Alegre for assistance to immigrants who, traditionally, tend to look for religious institutions rather than looking for governmental offices. More than that, the respondent admits that City Hall 'distributed' most of the immigrant assistance service to civil society entities, because the municipal government had only two employees (the respondent was one of the two). With meagre resources, some characteristics of SAPIDE/SMDH's performance were: informality (i.e. no attendance was recorded for subsequent monitoring and data collection), ad hoc assistance, discontinued support, re-activity (rather than pro-activity in policymaking and implementation), and little intersectorial activity with other municipal departments.

Indeed, a distinctive feature of this municipal institutional arrangement is the strong mobilisation of civil society around the theme of migration and refuge, and the institutionalisation of instances of participation at both municipal and state levels.

In 2012, the Committee for Attention to Migrants, Refugees, Stateless Persons and Victims of Trafficking in Persons of the State of Rio Grande do Sul (COMIRAT/RS) was established, with 34 members, including public authorities, international organisations, and civil society (State Decree 49 729/2012). In 2014, Porto Alegre established a homonymous committee in the municipality (COMIRAT/POA) through Municipal Decree $18815 / 2014$, which replaced the original law from the year 2000. Both decrees were the result of social struggles put forward by Rio Grande do Sul Permanent Forum on Human Mobility, a civil society network created in 2012, with the objective of 'fostering and expanding the network for reception, care, socio-cultural integration, advice, information, and knowledge production on human mobility' (Teixeira 2014: 19). 
The importance of civil society participation in municipal management should not be underestimated. Nonetheless, Respondent 2 observed problems, especially in the arrangement's intersectorial co-ordination. The respondent states that COMIRAT/POA is 'incipient', serving as a 'place for discussion [...], that does not make decisions, which is not propositional, and does not act jointly as a Committee' (Respondent 2, interview, 16 March 2017). The research shows that there has been little horizontal action between municipal secretariats other than emergency care for Haitians and Senegalese in 2014, i.e. during the study, we counted only one meeting with the Municipal Department of Education.

According to Respondent 2 (interview, 16 March 2017), migration gained priority on the Porto Alegre City Hall governmental agenda with the arrival of Haitians and Senegalese between 2013 and 2015. As mentioned before, the vast majority of these migrants arrived by bus from the State of Acre, chartered by the State Government of Acre, with support from the federal government. In November 2014, the most critical moment of the process, about 300 immigrants arrived in the city, but local authorities had not been notified and there was no reception strategy to host the group (Trezzi and Kannenberg 2014; Fraga 2015). According to the respondent, local authorities learned about what happened through the press and had to set up an emergency task force with the state government to host the group.

A very similar case occurred in São Paulo, which shows the lack of federative articulation between federal, state, and municipal governments to deal with migration issues. Porto Alegre City Hall was urged to act without prior planning or communication, and with no resources to deal with it alone. During the crisis, City Hall articulated an emergency task force with the state government to assist Haitian and Senegalese immigrants at the bus station, provisionally hosting them, according to Respondent 2 (interview, 16 March 2017). Subsequently, management tried to improve the conditions of care and shelter by presenting a project to the National Secretariat of Justice (SNJ) to implement the Porto Alegre Immigrant and Refugee Reference Centre (CRAI/POA). That strategy was also used in São Paulo, and it takes advantage of the willingness of SNJ to finally co-ordinate migration policies among federate entities.

The project was approved, and it resulted in an agreement between Porto Alegre City Hall and the National Secretariat of Justice (SNJ), having the State Government of Rio Grande do Sul as the intervening party. The agreement would have an expected duration of 24 months, and an estimated cost of 750000 Brazilian Reais (local currency), according to the Terms of Reference (SMDH 2015: 4). Also, according to the document, the state government was to assign the property that would house CRAI/POA, and the city would provide its rebuilding and management with federal resources. However, once again, the difficulty of federal co-ordination was unveiled: the state government did not assign the property as agreed, federal government did not act to enforce the agreement, and CRAI/ POA was never implemented. After this attempt, there was no more contact between the municipal and federal government (Respondent 2, interview, 16 March 2017). 
Although the lack of resources for the renovation of the property is allegedly the main reason for the project failure, Respondent 2 (interview, 16 March 2017) holds the opinion that there is a strategy of 'displacing' state government responsibility, using the excuse that 'people live in the municipality, [and therefore] the municipality can better serve them' (criticism extended to the federal government). For the respondent, the dynamic resembles a 'push game', in which the municipal government 'ends up' taking responsibility, and 'ends up' attending to immigrants precariously. After all, 'if the municipality does not do it, it is complete abandonment. State and federal government act as if they were not responsible.' Also, he adopts a critical perspective on the financing model, because the 'federal government finances the implementation of services, then withdraws it, and maintenance becomes a municipal responsibility' (Respondent 2, interview, 16 March 2017). Such criticism justifies, for example, the municipal government's fear of assuming migration policy, as mentioned beforehand.

The institutional arrangement developed in Porto Alegre has high permeability to civil society participation, and even some dependence on it, since there is low technical, human, and financial capability installed in SAPIDE/SMDH. In this scenario, the formulation and implementation of continuous and well-co-ordinated public policies are impaired, intersectorially and territorially, as evidenced by the inexistence of horizontal co-ordination within City Hall. Without a well-defined and vertically co-ordinated national migration policy, federal government cannot induce municipalities to strengthen local policies. The standpoint of municipal management in the period 2013-2016 is similar to the guest-worker policy type described by Alexander (2003), in which there is limited government action and responsibility is distributed to civil society. That also relates to the way public managers framed the problem before them: a temporary, transitory migration, which, therefore, did not require permanent capacity building in the municipality (including institutionalisation of municipal migration policy). In the next section, different results from the City of São Paulo will be examined.

\section{São Paulo: institutionalisation and decentralisation}

São Paulo, the capital city of the State of São Paulo, is recognised throughout Brazil as a cosmopolitan and diverse city, the home of millions of internal migrants and immigrants from abroad who have been coming to the country since the $18^{\text {th }}$ century. The historic role of labour attraction and it being the entry port of foreigners is reflected in migratory data. According to the Federal Police 2016 data, obtained through the Access to Information Act, there were 385000 active records of immigrants residing in the city, especially Portuguese, Bolivian, Japanese, Chinese and Italian.

Like the City of Porto Alegre, the task of hosting, integrating and defending the rights of internal migrants, immigrants, and refugees was carried out by entities affiliated to the Catholic Church established in the 1970s (Respondent 1, interview, 16 January 2017).

Also, according to Respondent 1 , the debate on municipalisation of migration and on promotion of universal citizenship dates back to 2006, inspired by the World Social 
Forum on Migration (WSFM) held in Spain in the same year. From then on, civil society addressed claims to City Hall, without success. Then, civil society turned to the legislature and was better received, so much so that the City Council approved Bill 196 of 2007 creating the Council of Foreign Communities, though it has never been implemented by City Hall.

The reluctance of São Paulo City Hall to institutionalise migratory policies does not mean total inaction towards the problems of the immigrant population. Since the 1990s, different municipal administrations have implemented relevant projects and initiatives, among which Respondent 1 highlighted the creation of Kantuta Square (an important meeting point for the Latino, especially Bolivian community), and projects to combat slave labour and assist migrant women victims of violence (Respondent 1, interview, 16 January 2017).

On the one hand, these processes are gradually strengthening social actors and enabling the emergence of new organisations and actors, and, on the other hand, they dig their way into state structures through making the bureaucracy aware of and sensitive to new immigrants (Tavares 2016: 45, translated by the authors).

Indeed, civil society was able to include the migration agenda in the 2012 mayoral campaign. The elected candidate created the Coordination Office for Migrant Policy (CPMig) within the newly created Municipal Secretariat of Human Rights and Citizenship (SMDHC), instrumented by Municipal Law 15764 of 2013. According to its official website, CPMig's objective is 'to articulate migratory public policies in the municipality, in a transversal, intersectorial and intersecretarial way'

At first sight, it is clear that, unlike Porto Alegre, the São Paulo administration immediately installed a team (which counted six employees) dedicated to the migratory issue, with its own financial resources, using the law as an instrument. The institutionalisation was deepened with the sanctioning of the Municipal Policy for the Immigrant Population - PMPI (Municipal Law 16478 of 2016), the first municipal policy dealing with the migratory issue as a whole to be found by this research, and which consolidated a series of public policies implemented by municipal administration from 2013 to 2016. Another contrast between the two cities compared in the article was the capacity in São Paulo to plan intersecretarial and intersectorial work involving other city government departments in the formulation and implementation of migration policies, strengthening the horizontal axis of the institutional arrangement.

Despite the criticism involving how horizontal policy co-ordination was put in practice ('the secretariats are interested in their goals, not in the SMDHC', Respondent 1 stated), several actions have been jointly implemented in the city, such as setting up shelters for migrants and the very formulation of the PMPI. The Municipal Council of Immigrants (CMI), created by Municipal Law 16478 of 2016, incorporated horizontal policy co-ordination by including eight municipal secretariats (e.g. Health, Culture and Housing) in this collegiate body. Contrary to what happened in Porto Alegre, the institution for social 
participation and intersectorial co-ordination in São Paulo was only created in the last year of the administration, and it had not been implemented by the end of 2016. Still, there had been dialogue with civil society and the government, for example through the $1^{\text {st }}$ Municipal Conference on Immigrant Policies, held in 2013.

The scenario shows that formulation and implementation of migration policy in the municipality of São Paulo began 'deliberately independent from federal government' (Respondent 1, interview, 16 January 2017). He emphasises that this was a political strategy of the municipal administration, because immigrants should be the ones to define working priorities and methodologies, through social participation. São Paulo would do it from the bottom up' (Respondent 1, interview, 16 January 2017). This bottom-up approach guided the relationship between federal government and the municipality. Local administration took a leading role in migration policy, in spite of lacking constitutional provisions and legal and financial incentives.

The characteristics of the vertical axis of the institutional arrangement become more evident from 2014 onwards, when the Haitians landed in São Paulo. The conditions were similar to those in Porto Alegre: 500 people arrived in chartered buses from the State of Acre, without prior communication to municipal and state governments, which prompted public complaints among mayors, governors and ministers (Folha de São Paulo 2014). Immigrants were precariously housed in the Nossa Senhora da Paz Church, as well as in an emergency shelter created by the City Hall, which housed over 2300 immigrants in 110 days (SMDHC 2014).

During this emergency period, a tripartite co-operation agreement was tailored, which distributed responsibilities between federal, state, and municipal governments. The agreement was signed on 30 May 2014, by the Minister of Justice, the São Paulo State Secretary of Justice and Citizenship, and the São Paulo Municipal Secretariat of Human Rights and Citizenship. The document was the first of its kind, in that it distributed responsibilities between spheres of government in a context of local emergency, proposing federative co-ordination. Under this agreement, the municipality would be responsible for housing, rights guidance, legal, psychological, and social assistance, language courses, and professional training, all to be implemented in co-financing agreements with federal government.

Respondent 1 (Interview, 16 January 2017) evaluates that the partnership was the result of pressure applied by the City of São Paulo. At the first meetings held with the National Secretariat of Justice (SNJ), federal government's position was that 'Acre and São Paulo should find a solution themselves, deepening the tension between the authorities involved, and, finally, exposing the improper co-ordination in the country's institutional arrangement. After thorough negotiation, SNJ agreed with the municipality on the transfer of 1.2 million Brazilian Reais and an 18-month term for the creation of the first Reference and Assistance Centre for Immigrants (CRAI/SP), to be supplemented by resources from the municipal treasury. According to Respondent 1 (Interview, 16 January 2017), that was when the dialogue for the tripartite co-operation agreement developed. 
To Respondent 1 (Interview, 16 January 2017), the model of voluntary transfer of funds via federal agreement is not ideal for permanent services, due to the complexity of implementing this type of partnership, and the issue of financial sustainability after the agreement expires, when city government would need to bear costs in full. It is noticeable that the interviewed municipal managers carry the same opinion about this financing model.

In 2015, after the implementation of CRAI/SP, dialogue between the City of São Paulo and federal government improved. The joint monitoring of CRAI allowed project adjustment, budget complementation, extension of term, and expansion of the number of Reception Centres for Immigrants, which required horizontal co-ordination within City Hall between two secretariats: Human Rights and Citizenship (SMDHC) and Assistance and Social Development (SMADS). The Coordination Office for Migrant Policy (CPMig/ SMDHC) was invited a few times to Brasília, along with other local governments, to discuss new solutions and proposals to deal with incoming Haitian immigrants and forms of expanding the 'CRAI Network.' One other agreement was signed, in which SMDHC provided physical space to establish a remote office of the National Council for Refugees (CONARE) in São Paulo, providing capillarity to the federal agency, yet without participation of municipal government. Also, there has been collaboration with the Ministry of Labour to guarantee the issuing of Documents for Labour Record (Carteiras de Trabalho) and to encourage the development of the Municipal Policy for Immigrants (PMPI) through consultancy provided by the Ministry and the International Labour Organisation (ILO).

The relationship between municipality and state was the least articulated. The state government complied with the tripartite agreement by setting up a temporary shelter for refugees and asylum seekers in São Paulo and delivering its Integrated Citizenship Centre for Immigrants (CIC Imigrantes), which offers the same services as CRAI, without formal co-ordination with City Hall. For Respondent 1 (interview, 16 January 2017), lack of partnership is due to political reasons (at the time, governments were run by competing parties) and lack of interest from the state government. He also criticises the policies implemented by the State Government of São Paulo, because he believes that such actions would be more useful if they were decentralised and implemented in smaller cities that do not have an active City Hall, again, an obstacle similar to that between Porto Alegre and the State Government of Rio Grande do Sul.

Even though São Paulo had similar difficulties to Porto Alegre, with regard to federative co-ordination, São Paulo managed to expand its capability to act on the migration issue, formalise a policy through municipal law, and implement public policy organisations with the participation of civil society, international organisations, and different municipal secretariats. Unlike the capital of Rio Grande do Sul, the migration agenda was already being implemented by the São Paulo administration when Haitian immigration came to the city, undergoing an adaptation. It can be said that the City of São Paulo acted from the outset to decentralise competences on migration policy, innovating in its policies, and influencing other municipalities (CRAI was later replicated in Porto Alegre). It is possible to see a 'pluralist' perspective in the city government concerning the migration issue, in 
the assumption that migrants are a constitutive part of São Paulo society, not a temporary issue whose responsibility could be distributed to civil society institutions, although these institutions still have a very important role in São Paulo.

\section{Final considerations}

This article aimed at bringing to light one of the main gaps in Brazilian migration policy, federative co-ordination. In order to accomplish that, we analysed the cases of two pioneer municipalities in local migration policies, Porto Alegre and São Paulo, and their relationship with the federal and state governments. Using an analytical approach to literature review and empirical research, we were able to demonstrate our conclusions, qualify the institutional arrangement of Brazilian migration policy, and make a critical analysis of it.

Migration management in Brazil was significantly influenced by the Foreigner's Statute from 1980 to 2017, when the New Migration Law was sanctioned. The statute was an anachronistic, centralising, and authoritarian law, focused on control over 'foreigners', protection of the national labour market, and regulation of entry and exit, neglecting integration of migrants residing in the country and protection of Brazilian nationals living abroad. Thus, ministries that co-ordinate social policies do not actively participate in the formulation of migration policy unless they are required to in response to some specific demand. This has implications at subnational levels of government given their constitutional competences, being largely responsible for implementing social integration policies.

Federate entities are, in fact, the least involved in the formulation and implementation of national migration policy, less so than most civil society organisations or international organisations with representatives in CNIg and CONARE. In addition to limited attention paid to integration policies, the fact that the Foreigner's Statute had been in force for 37 years (prior to democratisation and the process of decentralisation of social policies) may be interpreted as a major influence over the marginalisation of state and municipal governments. Even the 1988 Federal Constitution does not invite federate entities to assume attributions, placing migration policy under the responsibility of the federal government. These attributions show a clear distinction between who are the policymakers and the policy decision-makers in migration policy. Arretche (2012) warns us that without direct incentive or assignment, implementing a policy depends on the decision of mayors and governors, and many may look at some issues with suspicion - as seemed to be the case in the state of Rio Grande do Sul and its capital on the migratory agenda, as reported in interviews.

Our evaluation is that the lack of federative participation in institutional arrangements represents a serious shortcoming for migration policy. Medina et al (2009) draw attention to the fact that, even though subnational governments do not participate in policy decision-making, they will ultimately be responsible for managing integration of migrants, therefore they bear the burden of decisions made at the federal level. Analyses of two cases allowed us to confirm this statement, as well as to observe which policy model municipalities have adopted and which local institutional arrangements were being formed, their similarities and challenges. 
The capital city of São Paulo has innovated by creating a sector dedicated to immigrant population, by using the law as an instrument to settle a municipal policy with parity council and by implementing a series of permanent policies in different areas with municipal and federal investment. This policy dates back to the 2012 executive campaign for municipal administration, which means it is prior to the increase in the flow of immigration that prompted other governments to address the problem. The principles and guidelines of the municipal law of São Paulo show recognition of immigration as constitutive of the city dynamics, which calls for municipal authorities' attention.

The capital city of Rio Grande do Sul, Porto Alegre, has historic background experience on the subject, especially on refuge, although the absolute number of immigrants in the city is well below that of São Paulo. City Hall, under pressure from local civil society, constituted an institutional arrangement able enough to absorb social participation given the centrality of COMIRAT/POA. However, its institutionalisation was more fragile compared to the case of São Paulo. The committee had to be issued by decree, and the secretariat in charge had not formally constituted an agency on migration, nor was it endowed with technical staff and budget. The reason why so many policies do not get implemented, as in this example of CRAI/POA, is because of problems of federal co-ordination, as well as complete absence of state government participation and federal monitoring. Thus, we argue that the municipal government did not reject its immigrant population, but it looked at immigrants' issues as transitory and low priority, leaving most of the responsibility to civil society entities that have been dealing with immigrants for decades.

Given that subnational governments in Brazil have broad administrative autonomy, which means that the assumption of competences depends on the adhesion of the government level, Arretche (2011) explains that decentralisation is not homogeneous and depends on several factors. As it turned out, Brazil's centralising constitutional rules and the lack of financial, technical or legal induction by state and federal governments are both factors that prevent federative entities from taking responsibility and implementing policies for migrants.

Both municipalities analysed are subject to such negative factors. However, the country's largest and richest capital, São Paulo, was able to implement certain policies without depending on federal and state governments, which distinguishes it from Porto Alegre. São Paulo's municipal administration embraced the migration agenda, while Porto Alegre resisted it and required co-responsibility from state and federal governments. The fact that each administration acted in their own way may be attributed to factors of political culture - as both cities have a number of civil organisations around the theme - and a legacy of previous policies - specific actions that were being implemented during administrations prior to 2013.

Thus, São Paulo has advanced towards decentralising the policy for migrants, since it has institutionalised technical and administrative conditions and capabilities to assume management tasks, aiming at a continuous offer of services and goods. Porto Alegre moved in this direction but had a low level of institutionalisation and showed less confidence in following the policies implemented. The results of both administrations demon- 
strate differences in the ability to act on migratory flows and the problems that may arise from it. The experience of the City of São Paulo is more interesting from the point of view of strengthening state capacity. Shifts in government may change the scenario, and federal government incentives can change decentralisation. This is central when discussing the regulation of Article 120 of the New Migration Law, which can formally define the National Migration and Refuge Policy and the mechanisms of federative articulation.

Bearing this in mind, the analysis may come to a synthesis. Firstly, there is little or no action by the state governments, acknowledged by respondents from both capitals, reinforcing the absence of state entities in various policies, which had been reported in other studies (Arretche 2015; Lotta and Favareto 2016). In addition, respondents criticise policy co-ordination at federal level, and the lack of support from municipalities ('states and union wash their hands of this'). Municipal managers claim better articulation between federate entities. The respondent from São Paulo states that 'the success of municipal policy will depend on national policy,' and 'without a policy of [migratory] regularisation, everyone will "end up" at the [municipal] shelter.' He, then, argues, 'States need to be in politics even more than the municipality, concerning metropolitan regions and small [countryside] towns' (Respondent 1, interview, 16 January 2017).

Secondly, the policy funding model via voluntary fund transfer is not appropriate. Although there is no clear alternative proposal, respondents advocate a permanent funding model to ensure policy sustainability. Finally, it is observed that both federal government and the two municipalities are moving towards an inclusive migration policy, with non-criminalisation of immigrants, and respect for diversity, complying with human rights, in accordance to the New Migration Law. If the principles and guidelines adopted by federal and municipal laws are already in tune, the regulation of Article 120 may solve remaining problems, especially the formal inclusion of subnational governments in the institutional arrangement, with participation in decision-making, a sustainable funding model for services, clear division of competences, and decentralisation induction strategies. This regulation and subsequent impacts on local migration governance, if successful, may set an example on how to enable complex federative institutional arrangements, the type of which effectively protects the rights of migrants and addresses the challenges imposed by human mobility.

\section{Notes}

$1 \quad$ Federal Law No. 13445 of 24 May 2017.

2 This administrative division remained stable up to 2019, when the Ministry of Labour was extinguished by Federal Law No. 13844 of 2019. Its competences were divided between the Ministry of Economy and the Ministry of Justice and Public Safety.

3 It is important to clarify that the public policy envisioned by the Federal Government included the word 'Refugee' in the centre's name, which was adopted by the project put forward by Porto Alegre City Hall. São Paulo's administration, however, did not include the term. Nevertheless, it is the same policy, that is why the Portuguese acronym used is the same, 'CRAI.'

4 The use of the decree as an instrument for the creation of committees makes them more fragile in the event of a political change in administration. 


\section{References}

Alvesson, Mats and Dan Kärreman. 2007. 'Constructing mystery: Empirical matters in theory development.' Academy of Management Review 32 (4): 1265-1281.

Amrith, Megha. 2015. 'Pathways to urban citizenship for low-income migrants in São Paulo.' Citizenship Studies Journal 19 (6-7): 649-663.

Andena, Emerson A. 2013. Transformações da legislação imigratória brasileira: os (des)caminhos rumo aos direitos humanos. B.A. dissertation, University of São Paulo. At http://www.teses.usp.br/ teses/disponiveis/2/2140/tde-16122013-164856/pt-br.php [Accessed on 27 September 2019].

Aragaki, Sérgio S, Maria Lúcia C Lima, Camila C Q Pereira and Vanda Lúcia Nascimento. 2014. 'Entrevistas: Negociando sentidos e coproduzindo versões de realidade.' In Mary Jane Paris Spink, Jacqueline Isaac Machado Brigagão, Vanda Lúcia Vitoriano do Nascimento and Mariana PrioliCordeiro (eds), A produção de informação na pesquisa social: compartilhando ferramentas. Centro Edelstein de Pesquisas Sociais, pp. 57-72.

Arretche, Marta. 2004. 'Federalismo e Políticas Sociais no Brasil: problemas de coordenação e autonomia.' São Paulo em Perspectiva 18 (2): 17-26.

2011. Estado Federativo e políticas sociais: determinantes da descentralização. Rio de Janeiro: Revan.

2012. Democracia, Federalismo e Centralização no Brasil. Rio de Janeiro: FGV, Fiocruz.

Baraldi, Camila. 2014. Migrações Internacionais, Direitos Humanos e Cidadania Sul-Americana: o Prisma do Brasil e da Integração Sul-Americana. PhD Thesis. University of São Paulo, Brazil.

Bógus, Lúcia M M. and Viviane Rodrigues. 2011. 'Os refugiados e as políticas de acolhimento no Brasil: histórias e perspectivas.' Revista Dimensões - UFES 27: 101-114.

Borges, Andre. 2007. 'Desenvolvendo argumentos teóricos a partir de estudos de caso: o debate recente em torno da pesquisa histórico-comparativa.' Revista BIB 63: 45-59.

Câmara, A R T. 2014. Fluxos Migratórios para o Brasil no início do Século XXI: respostas institucionais brasileiras. B.A. dissertation. University of Brasília, Brazil.

Coentro, L U. 2011. Políticas Públicas e Gestão das Migrações Internacionais no Brasil: Uma reflexão sobre o migrante qualificado. B.A. dissertation. FGV-SP, Brazil.

Czaika, M and Hein De Haas. 2011. 'The effectiveness of immigration policies: A conceptual review of empirical evidence.' International Migration Institute Working Papers, No. 33.

Dizner, G F F. 2015. Política Externa e Política Migratória no Brasil: convergências e distanciamentos (1995-2010). B.A. dissertation. University of Brasília, Brazil.

Eisenhardt, K. 1989. 'Building theories from case study research.' Academy of Management Review 14 (4): 532-550.

Fauser, M. 2008. 'Autoridades locales e integración política en ciudades de nueva inmigración: Los casos de Madrid y Barcelona.' In R Zapata-Barrero and G Pinyol (eds), Actores y redes de actores en los procesos de inmigración en España y en Europa. Barcelona: Fundació CIDOB, pp. 131-148.

Fraga, R. 2015. 'Chegada de haitianos a Porto Alegre é adiada após pedido da prefeitura.' Portal G1 [online]. At http://g1.globo.com/rs/rio-grande-do-sul/noticia/2015/05/chegada-de-haitianos-porto-alegre-e-adiada-apos-pedido-da-prefeitura.html [Accessed on 20 July 2019]. 
Freitas, P T. 2016. 'Cidadania Local'. Revista E-Sesc: 44-45. At https://www.sescsp.org.br/online/artigo/9732_NOVAS+MIGRACOES [Accessed on 25 March 2017].

Gomes, C P. 2005. 'Os Estudos de Imigração: sobre algumas implicações políticas do método' In Hélion Póvoa Neto and A P Ferreira (eds), Cruzando Fronteiras Disciplinares: um panorama dos estudos migratórios. Rio de Janeiro: Revan, pp. 275-296.

Gomide, Anderson and Roberto Pires. 2014. Capacidades estatais e democracia: arranjos institucionais de políticas públicas. Brasília: Ipea.

Juzwiak, T, E McGregor and M Siegel. 2014. Migrant and Refugee Integration in Global Cities: the role of cities and businesses. Maastricht: Maastricht Economic and Social Research Institute on Innovation and Technology (UNU-MERIT); Maastricht Graduate School of Governance (MGSoG).

Lotta, Gabriela and Arilson Favareto. 2015. 'Desafios da integração nos novos arranjos institucionais de políticas públicas no Brasil.' Revista de Sociologia e Política 24: 49-65.

Martine, G. 2005. 'A globalização inacabada, migrações internacionais e pobreza no século 21.' São Paulo em Perspectiva 19 (3): 3-22.

Medina, Jorge A, Alba Leiras, Mohammed A. Haidour, Alicia Poza and Fernando R Sánchez. 2009. Las políticas locales para la integración de los inmigrantes y la participación de los agentes sociales. Madrid: Fundación 1er de Mayo.

Ministry of Foreign Affairs [Brazil] (MRE). 2015. Estimativas Populacionais das Comunidades. At http://www.brasileirosnomundo.itamaraty.gov.br/a-comunidade/estimativas-populacionais-das-comunidades [Accessed on 7 March 2017].

Moulin, Carolina and Diana Thomaz. 2016. 'The tactical politics of 'humanitarian' immigration: Negotiating stasis, enacting mobility.' Citizenship Studies 20 (5): 595-609.

International Organisation for Migration (IOM). 2011. Glossary on Migration: 2nd edition. At www. publications.iom.int/system/files/pdf/iml25_1.pdf [Accessed on 29 July 2019].

2015. World Migration Report 2015: Migrants and Cities, New Partnerships to Manage Mobility. Geneva: International Organization for Migration.

International Organisation for Migration (IOM) and Institute of Public Policies And Human Rights Of Mercosur (IPPDH). 2017. Diagnóstico regional sobre migración haitiana. Buenos Aires: International Organization for Migration.

Otero, Guilherme. 2017. Migrações, Políticas Públicas e Federalismo: Análise da política migratória brasileira a partir da abordagem dos arranjos institucionais. B.A. Dissertation. Universidade Federal do ABC, Brazil.

Porto Alegre Municipal Secretariat of Human Rights (SMDH). s.d. 'SAPIDE - Sobre os Refugiados e Imigrantes.' At http://www2.portoalegre.rs.gov.br/smdh/default.php?p_secao=90. [Accessed on 5 April 2017].

2015. Termo de Referência: Implantação de Centro de Referência e Acolhida para Imigrantes e Refugiados no Centro Humanístico Vida no Município de Porto Alegre (CRAI/POA). Porto Alegre.

São Paulo Municipal Secretariat of Human Rights and Citizenship (SMDHC). s.d. Homepage, Coordenação de Políticas para Migrantes (MPMig). At http://www.prefeitura.sp.gov.br/cidade/secretarias/direitos_humanos/migrantes/coordenacao/index.php?p=156223 [Accessed on 30 March 2017]. 
2014. Abrigo Emergencial PMSP - Relatório Final. At http://www.prefeitura.sp.gov.br/cidade/secretarias/upload/direitos_humanos/Relatorio\%20Final\%20Abrigo\%20Emergencial.pdf [Accessed on 30 March 2017].

Sassen, Saskia. 2005. 'The global city: Introducing a concept.' The Brown Journal of World Affairs 11 (2): 27-43.

Teixeira, A N. 2014. O Fórum Permanente de Mobilidade Humana e a produção de políticas públicas para migrantes haitianos no Rio Grande do Sul. B.A. dissertation. Universidade Federal do Rio Grande do Sul, Brazil.

Trezzi, H and V Kannenberg. 2014. 'Sem avisar, Acre envia quatro ônibus com haitianos ao RS.' Portal Zero Hora [online]. At https://gauchazh.clicrbs.com.br/geral/noticia/2014/11/Sem-avisar-Acreenvia-quatro-onibus-com-haitianos-ao-RS-4651306.html [Accessed on 20 July 2019].

United Nations (UN). 2016. International Migrant Stock: The 2015 Revision. United Nations, Population Division, Department of Economic and Social Affairs. At http://www.un.org/en/development/ desa/population/migration/data/estimates2/estimates15.shtml [Accessed on 28 August 2016].

2017. New Urban Agenda. At http://habitat3.org/wp-content/uploads/NUA-English.pdf [Accessed on 15 January 2020].

United Nations High Commissioner for Refugees (UNHCR) and International Organization for Migration (IOM). 2019. US\$1.35 billion needed to help Venezuelan refugees and migrants and host countries. Geneva. At https://r4v.info/es/documents/download/72455 [Accessed on 19 January 2020].

Zamberlam, G, G Corso, J Filippin and L Bocchi. 2009. 50 anos com os migrantes - Paróquia da Pompéia, uma Missão Scalabriniana. Porto Alegre: Solidus.

Zamberlam, J, L Bocchi, G Corso and J M Cimadon. 2013. Imigrante - A Fronteira da documentação e o difícil acesso às políticas públicas em Porto Alegre. Porto Alegre: Solidus.

Zamberlan, Jurandir. 2013. Imigração e Políticas Públicas aos Imigrantes em Porto Alegre. Porto Alegre, CIBAI-Migrações. At http://www.participa.br/articles/public/0006/6528/Imigra\%C3\%A7ao_e_ Pol.P\%C3\%Bablica._Porto_Alegre.pdf [Accessed on 24 August 2019].

Zolberg, Aristide R. 2000. 'The dawn of cosmopolitan denizenship.' Indiana Journal of Legal Studies 7 (2): 511-518.

\section{Legislation references}

Brazil. 1980. Federal Law No. 6 815. At http://www.planalto.gov.br/ccivil_03/leis/L6815.htm [Accessed on 23 March 2020].

1988. Federal Constitution. At http://www.planalto.gov.br/ccivil_03/constituicao/constituicao.htm [Accessed on 23 March 2020].

. 1998. Federal Law No. 9 649. At http://www.planalto.gov.br/ccivil_03/LEIS/L9649cons.htm

[Accessed on 23 March 2020].

.2017. Federal Law No. 13 445. At http://www.planalto.gov.br/ccivil_03/_Ato2015-2018/2017/

Lei/L13445.htm [Accessed on 23 March 2020]. 
Porto Alegre. 2000. Municipal Law No. 8 593. At http://www2.portoalegre.rs.gov.br/cgi-bin/nphbrs? $\mathrm{u}=/$ netahtml/sirel/avancada.html $\& \mathrm{p}=11 \& \mathrm{r}=208 \& \mathrm{f}=\mathrm{G} \& \mathrm{~d}=\mathrm{ATOS} \& \mathrm{l}=20 \& \mathrm{~s} 1=($ ESTATUTO $)$. RELA [Accessed on 23 March 2020].

2002. Municipal Act No. 13 717. At http://www2.portoalegre.rs.gov.br/cgi-bin/nph-brs?u=/ netahtml/sirel/avancada.html\&p=1\&r=1\&f=G\&d=ATOS\&l=20\&s4=@data\%3E=20020101\%20 \%3C=20023112\&s2=Decreto\%20Municipal\&s3=\%2213717\%22 [Accessed on 23 March 2020].

2012. Municipal Law No. 11 399. At http://www2.portoalegre.rs.gov.br/cgi-bin/nph-brs?u=/ netahtml/sirel/avancada.html\&p=1\&r=1\&f=G\&d=ATOS\&l=20\&s4=@data\%3E=20120101+\%3C= 20123112\&s2=Lei+Municipal\&s3=\%2211399\%22 [Accessed on 23 March 2020].

2013. Municipal Act No. 18 163. At: http://www2.portoalegre.rs.gov.br/cgi-bin/nph-brs?u=/ netahtml/sirel/simples.html\&p=6\&r=105\&f=G\&n=-DATA\&d=ATOS\&l=20\&s1=6309 [Accessed on 23 March 2020].

2014. Municipal Act No. 18 583. At http://www2.portoalegre.rs.gov.br/cgi-bin/nph-brs?u=/ netahtml/sirel/avancada.html\&p=61\&r=1201\&f=G\&d=ATOS\&l=20\&s1=(ATRIBUICAO).. RELA [Accessed on 23 March 2020].

2014. Municipal Act No. 18 815. At http://www2.portoalegre.rs.gov.br/cgi-bin/nph-brs?u=/ netahtml/sirel/avancada.html\&p=5\&r=85\&f=G\&d=ATOS\&l=20\&s1=(Inclus\%E3o)..RELA. [Accessed on 23 March 2020].

Rio Grande Do Sul. 2012. State Decree No. 49 729. At http://www.al.rs.gov.br/filerepository/repLegis/arquivos/DEC\%2049.729.pdf [Accessed on 23 March 2020].

São Paulo. 2007. Municipal Bill No. 196. 2007. At https://leismunicipais.com.br/a2/sp/s/sao-paulo/ projeto-de-lei-ordinaria/2007/19/196/projeto-de-lei-ordinaria-n-196-2007-dispoe-sobre-o-conselho-das-comunidades-estrangeiras-e-da-outras-providencias [Accessed on 23 March 2020].

2013. Municipal Law No. 15 764. At https:/www.prefeitura.sp.gov.br/cidade/secretarias/ governo/legislacao/index.php?p=170844 [Accessed on 23 March 2020].

2016. Municipal Law No. 16 478. At http://legislacao.prefeitura.sp.gov.br/leis/lei-16478-de08-de-julho-de-2016/detalhe [Accessed on 23 March 2020]

2016. Municipal Act No. 57 533. At http://legislacao.prefeitura.sp.gov.br/leis/decreto-57533de-15-de-dezembro-de-2016/ [Accessed 23 March 2020].

\section{Interviews}

Respondent No. 1 (Co-ordination Office for Migrant Policy, São Paulo Municipal Secretariat of Human Rights and Citizenship). 2017. Personal interview by Guilherme Otero. São Paulo, 16 January.

Respondent No. 2 (Joint Secretariat of the Indigenous People and Specific Rights, Porto Alegre Municipal Secretariat of Human Rights). 2017. Telephone interview by Guilherme Otero. Porto Alegre, 16 March.

Respondent No. 3 (National Secretariat of Justice, Ministry of Justice [Brazil]). 2017. Telephone interview by Guilherme Otero. Brasília, 24 January.

Respondent No. 4 (National Immigration Council, Ministry of Labour [Brazil]). 2017. Telephone interview by Guilherme Otero. Brasília, 30 March. 


\section{Acknowledgments}

The views and opinions expressed in this article are those of the authors and do not necessarily reflect the official policy or position of IOM.

\section{About the authors}

Guilherme Arosa Prol Otero holds a Master's Degree in Public Policy from the Federal University of ABC (UFABC), B.A. in International Relations from the University of São Paulo (USP). Former Technical Advisor and Deputy-Coordinator in the São Paulo Coordination Office of Policies for Migrants (2013-2016), and former member of the university extension project 'Educar para o Mundo' (2009-2012), which aimed to bridge the gap between migrant communities and the public university. Currently Project Coordinator at the International Organization for Migration (IOM) in Brazil.

Gabriela Spanghero Lotta is a professor and researcher in Public Administration and Government at Fundação Getúlio Vargas (FGV). Postgraduate professor in Public Policy at Federal University of ABC (UFABC). Ph.D. in Political Science from USP, Master's and Bachelor's Degree in public administration from Fundação Getúlio Vargas. Coordinator of the Bureaucracy Studies Centre (NEB). Professor at the National School of Public Administration, ENAP. Coordinator of the Thematic Area State and public policies of the Brazilian Association of Political Science (ABCP) and research director of the National Association of Teaching and Research of the Public Field (ANEP/CP). Has worked with consultancy, research and training for several administrations. 


\section{Migração Internacional e Co-ordenação Federativa no Brasil: Estudos de Caso de São Paulo e Porto Alegre entre 2013 e 2016}

Resumo: Este artigo analisa a coordenação entre governos nacionais e municipais no Brasil em relação à política de migração entre os anos de 2013 e 2016, utilizando o conceito de arranjos institucionais de políticas e estudos de caso de duas cidades brasileiras, São Paulo e Porto Alegre. Os resultados revelam que o governo da cidade de São Paulo avançou consideravelmente no sentido de institucionalização do sujeito no município, descentralizando habilidades e assumindo responsabilidades sobre a população migrante, com relativa autonomia do Governo Federal. O governo da cidade de Porto Alegre mostra um arranjo menos institucionalizado, com pouca capacidade técnica e financeira, menos autonomia dos governos Federal e estaduais e grande ênfase na participação da sociedade civil. Finalmente, defende-se que a regulamentação da Nova Lei de Migração possa lidar com uma série de problemas no atual arranjo federativo, constituindo políticas articuladas por federações, com maior capacidade de implementação de políticas públicas e participação mais ativa dos governos subnacionais no desenvolvimento da política nacional de migração.

Palavras-Chave: migração internacional; política migratória; arranjo institucional; políticas públicas; políticas de integração.

Received on 28 September 2019, and approved for publication on 4 February 2020.

\section{(c) BY-NC} https://creativecommons.org/licenses/by-nc/4.0/ 